\title{
Optimising surgical approaches to the orbit - a retrospective analysis of a series of forty orbital tumours
}

\author{
Sudha Menon $\odot^{1}$, Vyjayanth Reddy', Arya Ravindran Poduval', Girish Menon $\odot^{2}$ \\ 'Department of Ophthalmology, Manipal Academy of Higher Education, Manipal, India \\ ${ }^{2}$ Department of Neurosurgery, Manipal Academy of Higher Education, Manipal, India
}

\begin{abstract}
BACKGROUND: This study aimed to analyse the influence of location, pathology, and approach on the extent of resection of orbital tumours.

MATERIAL AND METHODS: We have conducted a retrospective analysis of the clinico-radiological features of all orbital tumours operated between January 2012 and December 2019. Frontotemporal craniotomy with orbitotomy was performed for almost all lesions, except those limited to the lateral compartment (lateral orbitotomy), superior compartment (mini-craniotomy), and inferior medial compartment (transconjunctival/endoscopy). Statistical Analysis System (SAS) version 9.4 was used for analysis, and a p-value $<0.05$ was considered to be statistically significant. The study was approved by the Institutional Review Board (3/10/2020).

RESULTS: Our study group comprised forty patients with a mean age of 40.89 years \pm 19 years. Of the forty tumours, $21(52.5 \%)$ cases were primary tumours of the orbit, and 19 (47.5\%) were secondary tumours. The majority, 27 $(67.5 \%)$, of the tumours were extraconal in location. The two most common presenting symptoms were proptosis $(36 / 40 ; 90 \%)$ and visual blurring $(30 / 40 ; 75 \%)$. The majority of the patients could be successfully operated through a fronto-tempero-orbital approach with or without removal of zygoma (28/40; 70\%). Meningioma was the most common histology (45\%), followed by schwannoma and lacrimal gland tumours (10\%). Primary orbital tumours $(15 / 21 ; 71.6 \%)$ and intraconal tumours $(9 / 13 ; 69.23 \%)$ were associated with greater rates of gross total removal (GTR). GTR in sphenoorbital meningiomas was poor $(2 / 17 ; 11.8 \%)$.

CONCLUSION: Intraconal primary benign orbital tumours have a better chance of total gross removal. A frontotempero-orbital approach with or without removal of zygoma provides adequate exposure for the majority of the tumours.
\end{abstract}

KEY WORDS: orbit; orbital tumours; craniotomy; lateral orbitotomy

\section{INTRODUCTION}

The orbit encases the ocular globe with its appendages. Tumours of the orbit include a broad spectrum of pathologies [1-3]. Its unique anatomi- cal outline and its proximity to the cranial cavity make surgical approaches to the orbit a challenging pursuit [4]. Different surgical corridors have been described to access the orbit, each customised 
based on the location of the tumour and its pathology. The primary guiding principle is the location of the lesion within the orbit and its relation to the globe and neurovascular structures. Successful management of orbital tumours involves a multidisciplinary approach involving ophthalmologists, neurosurgeons, endonasal surgeons, and plastic surgeons. Although orbital tumours are not uncommon, Indian literature on surgical management of orbital tumours is limited. This study aims to analyse and highlight the challenges involved in the surgical management of a single institute series of forty patients with orbital tumours

\section{MATERIAL AND METHODS}

Retrospective analysis of the clinico-radiological features of all orbital tumours operated in a single institute between January 2012 and December 2019. A detailed ophthalmological and neurological assessment was done preoperatively in all the patients. Visual acuity (VA) was evaluated using the Snellen chart, and visual field (VF) was measured using the Humphrey automated perimetry or the Goldmann perimetry. The exophthalmos index as described by Scarone was used to measure the exophthalmos radiologically [5]. Our surgical policy was to perform a frontotemporal craniotomy with orbitotomy (FTO) for all lesions in the superior compartment (intra- and extraconal), those reaching the orbital apex, and those with intracranial extension. An extended fronto-temperozygomatico-orbital craniotomy (FTZO) was reserved for lesions with extensive intracranial extensions. Similarly, a minimal approach in the form of suprabrow mini-fronto-orbital craniotomy was used if the lesion was restricted to the superior compartment alone. Lesions limited to the lateral compartment were approached through a lateral orbitotomy. Medial orbital lesions, especially in the inferior compartment, were approached preferably either through a transconjunctival approach or through an endoscopic approach. The extent of removal was graded as GTR (90-100\%), subtotal removal (STR) (25-90\%), partial removal/biopsy. All patients underwent a serial visual examination in the postoperative period and a repeat magnetic resonance imaging (MRI) at three months. Influence of location, pathology, and approach to the extent of resection was analysed using Statistical Analysis System (SAS) version 9.4). A p-value $<0.05$ was considered statistically significant. The study was initiated after get- ting approval from the Institutional Review Board (310/2020) and following strict adherence to the guidelines of the Declaration of Helsinki.

\section{RESULTS}

Our study group comprised forty patients with a mean age of 40.89 years $+/-19$ years. Both sexes were represented equally $(\mathrm{M}: \mathrm{F}=17: 23)(\mathrm{Tab} .1)$. Of the forty tumours, $21(52.5 \%)$ cases were primary tumours of the orbit, and $19(47.5 \%)$ were secondary tumours. The majority ( $27 / 40 ; 67.5 \%$ ) of the tumours were extraconal in location, and the remaining $(13 / 40 ; 32.5 \%)$ were intraconal. The two most common presenting symptoms were proptosis

Table 1. Demographics, clinical features, location and histology of the forty patients with orbital tumours

\begin{tabular}{|c|c|}
\hline Patients & $n=40$ \\
\hline $\operatorname{Sex}[M / F]$ & $17: 23$ \\
\hline Mean age [yrs] & $40.89 \pm 19$ \\
\hline Mean follow-up [mo] & 13 \\
\hline \multicolumn{2}{|l|}{ Symptoms } \\
\hline Proptosis & 36 \\
\hline Diplopia & 13 \\
\hline Visual acuity decrease & 30 \\
\hline Trigeminal hypoesthesia & 10 \\
\hline Retro/peri bulbar pain & 24 \\
\hline \multicolumn{2}{|l|}{ Tumour origin } \\
\hline Primary orbital tumour & 21 \\
\hline Secondary tumours & 19 \\
\hline \multicolumn{2}{|l|}{ Location } \\
\hline Extraconal & 27 \\
\hline Intraconal & 13 \\
\hline \multicolumn{2}{|l|}{ Histology } \\
\hline Optic nerve glioma & 02 \\
\hline Cavernoma/haemangioma & 03 \\
\hline Schwannoma & 04 \\
\hline Granuloma/pseduotumour & 02 \\
\hline Lymphoma & 02 \\
\hline Lacrimal gland tumour & 04 \\
\hline Rhabdomyosarcoma & 01 \\
\hline Langerhans cell histiocytosis & 01 \\
\hline Metastasis & 01 \\
\hline Mucocole & 01 \\
\hline Hemangioblastoma & 01 \\
\hline Optic nerve sheath meningioma & 01 \\
\hline Meningiomas - sphenoorbital & 17 \\
\hline
\end{tabular}




\begin{tabular}{|c|c|c|c|c|c|c|c|c|}
\hline Age & Sex & $\begin{array}{l}\text { Presenting } \\
\text { complaints }\end{array}$ & $\begin{array}{c}\text { Duration } \\
\text { of symptoms } \\
\text { [mo] }\end{array}$ & $\begin{array}{c}\text { Extent } \\
\text { of resection }\end{array}$ & Histopathology & Radiation & Resurgery & $\begin{array}{l}\text { Follow-up } \\
\text { [mo] }\end{array}$ \\
\hline 52 & $F$ & $\begin{array}{l}\text { Proptosis, vision, } \\
\text { headache }\end{array}$ & 22 & STR & Atypical & RT & Yes & 38 \\
\hline 32 & $\mathrm{~F}$ & $\begin{array}{l}\text { Proptosis, vision, } \\
\text { headache }\end{array}$ & 34 & STR & Grade I & No & No & 36 \\
\hline 43 & $\mathrm{~F}$ & $\begin{array}{c}\text { Proptosis, headache, } \\
\text { vision }\end{array}$ & 12 & STR & Grade I & RT & No & 54 \\
\hline 64 & $\mathrm{~F}$ & $\begin{array}{l}\text { Proptosis, vision, } \\
\text { headache }\end{array}$ & 8 & STR & Grade I & No & No & 32 \\
\hline 60 & $F$ & $\begin{array}{l}\text { Proptosis, vision, } \\
\text { headache }\end{array}$ & 36 & STR & Atypical & RT & Yes & 68 \\
\hline 59 & $\mathrm{M}$ & Proptosis, headache & 54 & STR & Grade I & No & No & 72 \\
\hline 44 & $F$ & Vision, headache & 33 & GTR & Grade I & RT & No & 86 \\
\hline 49 & $\mathrm{~F}$ & Proptosis, headache & 22 & STR & Grade I & RT & No & 46 \\
\hline 72 & $F$ & Vision, headache & 18 & STR & Grade I & No & No & 56 \\
\hline 17 & $\mathrm{M}$ & Proptosis, vision & 26 & STR & Grade I & No & No & 68 \\
\hline 52 & $F$ & $\begin{array}{c}\text { Proptosis, facial } \\
\text { paraesthesia, vision }\end{array}$ & 42 & STR & Grade I & No & No & 72 \\
\hline 40 & $F$ & $\begin{array}{l}\text { Proptosis, vision, } \\
\text { headache }\end{array}$ & 60 & STR & Grade I & RT & No & 48 \\
\hline 44 & $F$ & Vision, headache & 36 & STR & Grade I & No & No & 54 \\
\hline 69 & $\mathrm{~F}$ & $\begin{array}{l}\text { Proptosis, vision, } \\
\text { facial paraesthesia }\end{array}$ & 45 & STR & Grade I & No & No & 62 \\
\hline 68 & M & $\begin{array}{l}\text { Proptosis, facial } \\
\text { paraesthesia's, } \\
\text { headache }\end{array}$ & 52 & STR & Atypical & RT & Yes & 36 \\
\hline 41 & $F$ & Proptosis, vision & 38 & GTR & Grade I & No & No & 74 \\
\hline 54 & M & $\begin{array}{l}\text { Proptosis, vision, } \\
\text { facial paraesthesia }\end{array}$ & 28 & STR & Grade I & RT & No & 54 \\
\hline
\end{tabular}

GTR — gross total removal; STR — subtotal removal; RT — radiotherapy

(36/40; 90\%) and visual blurring (30/40; 75\%). Retro-/peribulbar pain $(24 / 40 ; 60 \%)$, diplopia $(13 / 40 ; 32.5 \%)$ paresthesias in the trigeminal distribution $(10 / 40 ; 25 \%)$, were the other presenting symptoms.

The histopathological diagnosis of the lesions is shown in Table 1. All the sphenoorbital meningiomas were approached through a fronto-tempero-orbitozygomatic approach (Tab. 2). Tumour and location-specific approaches were used for the other lesions, as is shown in Table 3. Lateral orbitotomy was used in six patients, anterior transconjunctival approach - in two, fronto-temporo-orbital - in ten, and suprabrow frontal mini-craniotomy - in four. An endoscopic approach was used to remove the residual medial schwannoma after a transcranial approach failed to remove the lesion completely. GTR in sphenoorbital menin- giomas was poor and could be achieved in only two patients (11.8\%) in this series (Tab. 2). In the other 23 pathologies, GTR could be achieved in 14 (60.86), STR in 4 (17.4\%), and partial removal in $6(26.2 \%)$ (Tab. 3). Better total resection rates were seen in the primary orbital tumors $(15 / 21 ; 71.6 \%)$ compared to extraorbital tumors $(3 / 19 ; 15.2 \%)$. However, the difference was not significant $(\mathrm{p}=0.698)$. Similarly, intraconal tumours had a statistically significant greater chance of GTR $(9 / 13 ; 69.23 \%)$ than extraconal tumours $(07 / 27 ; 25.9 \%)(\mathrm{p}$-value $=.015)$. FTZO approach was associated with a poor rate of GTR (16.6\%; $\mathrm{p}$-value $=.001)$ probably related to the underlying pathology as a majority were sphenoorbital meningiomas (Tab. 4). Improvement in vision and proptosis was suboptimal in sphenoorbital meningiomas. After surgery, proptosis improved in nine 


\begin{tabular}{|c|c|c|c|c|c|c|c|}
\hline $\begin{array}{l}\text { Age, } \\
\text { Sex }\end{array}$ & Presentation & Nature & Location & Histopathology & Approach & $\begin{array}{l}\text { Extent } \\
\text { of resection }\end{array}$ & Complications \\
\hline $\mathrm{M}, 40$ & $\begin{array}{c}\text { Proptosis, diplopia, } \\
\text { periorbital pain }\end{array}$ & Primary & Intraconal & Optic nerve glioma & FTZO & GTR & Wound leak \\
\hline $\mathrm{M}, 48$ & $\begin{array}{l}\text { Propotsis, } \\
\text { retroprbital pain }\end{array}$ & Primary & Extraconal & $\begin{array}{l}\text { Lacrimal gland tumour } \\
\text { with infection }\end{array}$ & LO & GTR & $\begin{array}{l}\text { Infection, motility } \\
\text { restriction }\end{array}$ \\
\hline$F, 38$ & Propotsis & Primary & Intraconal & Schwannoma & FTO & GTR & No \\
\hline$F, 65$ & $\begin{array}{c}\text { Proptosis, diplopia, } \\
\text { periorbital pain }\end{array}$ & Primary & Intraconal & Spindle cell haemangioma & FTO & STR & No \\
\hline $\mathrm{F}, 5$ & Periorbital pain & Primary & Intraconal & Optic nerve glioma & FTO & Partial & Recurrence \\
\hline$F, 32$ & Proptosis & Primary & Intraconal & $\begin{array}{l}\text { Intraorbital meningioma? } \\
\text { Optic nerve sheath }\end{array}$ & FTO & Partial & No \\
\hline$M, 25$ & Proptosis & Primary & Extraconal & $\begin{array}{l}\text { Poorly differentiated } \\
\text { adenocarcinoma }\end{array}$ & LO & Partial & $\begin{array}{l}\text { Recurrence } \\
\text { - both eyes }\end{array}$ \\
\hline $\mathrm{F}, 26$ & Proptosis & Primary & Intraconal & Schwannoma & LO & GTR & No \\
\hline $\mathrm{F}, 35$ & $\begin{array}{c}\text { Trigeminal } \\
\text { hypoesthesia }\end{array}$ & Primary & Intraconal & $\begin{array}{c}\text { Optic nerve } \\
\text { glioma/haemangioblastoma }\end{array}$ & ATC & GTR & No \\
\hline $\mathrm{F}, 72$ & $\begin{array}{l}\text { Propotosis, } \\
\text { periorbital pain }\end{array}$ & Primary & Extraconal & $\begin{array}{l}\text { Lacrimal gland } \\
\text { adenocarcinoma }\end{array}$ & LO & GTR & CSF leak, recurrence \\
\hline M.41 & Retroorbital pain & Primary & Intraconal & Cavernous haemangioma & FTO & GTR & No \\
\hline $\mathrm{M}, 38$ & Diplopia & Primary & Intraconal & Schwannoma & $\begin{array}{c}\text { FTO, } \\
\text { Endoscopic }\end{array}$ & GTR & $\begin{array}{c}\text { Recurrence, } \\
\text { decreased vision }\end{array}$ \\
\hline $\mathrm{F}, 64$ & Diplopia & Primary & Intraconal & NHL & LO & GTR & Recurrence \\
\hline$M, 0.3$ & Proptosis & Primary & Extraconal & Rhabdomyosarcoma & SMC & STR & Recurrence \\
\hline $\mathrm{M}, 12$ & Proptosis, diplopia & Primary & Intraconal & Cavernous haemangioma & FTO & GTR & No \\
\hline $\mathrm{M}, 9$ & Proptosis & Primary & Extraconal & Eosinophilic granuloma & SMC & GTR & No \\
\hline$M, 44$ & Diplopia & Secondary & Extraconal & $\begin{array}{l}\text { Metastatic neuroendocrine } \\
\text { carcinoma }\end{array}$ & FTO & Partial & No \\
\hline$M, 59$ & Proptosis & Primary & Extraconal & NHL & ATC & STR & No \\
\hline M, 27 & Proptosis & Primary & Intraconal & Schwannoma & FTO & GTR & No \\
\hline$M, 57$ & Retrorobital pain & Secondary & Extraconal & Mucocoele & SMC & GTR & No \\
\hline$F, 64$ & $\begin{array}{l}\text { Diplopia, } \\
\text { retroorbital pain }\end{array}$ & Primary & Extraconal & $\begin{array}{l}\text { Lacrimal gland } \\
\text { adenocarcinoma }\end{array}$ & LO & STR & Ptosis, visual loss \\
\hline$M, 43$ & Diplopia, pain & Primary & Intraconal & Pseudotumour & FTO & Partial & No \\
\hline $\mathrm{F}, 35$ & $\begin{array}{c}\text { Proptosis, } \\
\text { periorbital pain }\end{array}$ & Primary & Extraconal & Granuloma & SMC & Partial & Sepsis \\
\hline
\end{tabular}

NHL — non-Hodkin's lymphoma; FTO — fronto-tempero-orbital craniotomy; LO — lateral orbitotomy; SMC — suprabrow mini-craniotomy; GTR — gross total removal; STR — subtotal removal

$(64.3 \%)$, and vision improved in four patients (28.6\%). In the remaining twenty-three patients, vision and proptosis improved in 10/16 (62.5\%) and 18/22 (81.8\%) patients, respectively (Tab. 5). Following surgery, two (14.3\%) patients who had severe visual deficits pre-operatively showed deterioration in their vision. In addition, one patient lost vision following lateral orbitotomy for a lacrimal gland tumour due to injury to the ophthalmic artery. One patient with a sphenoorbital meningioma developed an extradural hematoma which had to be evacuated. Four patients developed oculomotor nerve palsy in the post-operative period, and this persisted for about six months in two patients. Two patients developed disabling facial hyperesthesia over the distribution of the trigeminal nerve. The hyperesthesia was partially controlled with medications. Mechanical causes accounted for restricted ocular motility in eight patients. These disturbances improved with time. Cosmetically disabling enophthalmos was observed in only two patients (Tab. 5). 
Table 4. Extent of resection comparison based on location and approach

\begin{tabular}{|c|c|c|c|}
\hline & Number & Gross total resection & p-value \\
\hline \multicolumn{4}{|l|}{ Type } \\
\hline Primary & 21 & 15 (71.6\% & $0.698^{*}$ \\
\hline Secondary & 19 & $03(15.2 \%)$ & \\
\hline \multicolumn{4}{|l|}{ Location } \\
\hline Intraconal & 13 & $09(69.23 \%)$ & $0.015^{*}$ \\
\hline Extraconal & 27 & $07(25.9 \%)$ & \\
\hline \multicolumn{4}{|l|}{ Approach } \\
\hline FTZO & 18 & $03(16.6 \%$ & $0.001 * *$ \\
\hline Frontotemporal orbitotomy & 10 & $08(80 \%)$ & \\
\hline Lateral orbitotomy & 06 & $05(83.3 \%)$ & \\
\hline SMC & 04 & 03 (75\%) & \\
\hline
\end{tabular}

FTZO — fronto-temperozygomatico-orbital craniotomy; SMC — suprabrow mini-craniotomy

Table 5. Post operative outcome (vision and proptosis) and complications

\begin{tabular}{|l|c|}
\hline \multicolumn{2}{|l|}{ Post operative outcome - vision and proptosis } \\
\hline \multicolumn{2}{|l|}{} \\
\hline Sphenoorbital \\
\hline Vison & $28.6 \%$ \\
\hline Proptosis & $64.3 \% \%$ \\
\hline Other tumours \\
\hline Vision & $62.5 \%$ \\
\hline Proptosis & $81.8 \%$ \\
\hline Complications & \\
\hline Visual acuity deterioration & 03 \\
\hline Disabling facial paraesthesias & 02 \\
\hline Third cranial nerve palsy & 04 \\
\hline Mechanical restriction of ocular motility & 08 \\
\hline Enophthalmos & 02 \\
\hline
\end{tabular}

\section{DISCUSSION}

\section{Relevant anatomy}

Orbital anatomy is complex, and a thorough knowledge of orbital anatomy is a prerequisite in the surgical management of orbital tumours [6-9]. The bony orbit is pyramidal and has an approximate volume of $30 \mathrm{~cm}^{3}$. The bony margins of the orbit are made up of seven bones, namely - frontal, ethmoid, lacrimal, sphenoid, zygomatic, palatine, and maxilla. The orbit has a roof, lateral wall, floor, and medial wall, and the apex is directed posteriorly. The optic canal and superior orbital fissure form the apex of the pyramid, which is tilted medially. The lateral walls of the orbits make a right angle with each other. The periorbita lines the orbital bones and merges with the dura at the optic canal and near the superior orbital fissure. Eight muscles within the orbit control the movements of the globe and eyelids.

The recti and the superior oblique arise from the tendinous ring called the annulus of Zinn and the adjacent bone at the apex of the orbit and insert into the sclera. The levator palpebrae superioris originates at the orbital apex, forms an aponeurosis, and inserts into the upper eyelid. The Optic nerve leaves the orbit through the optic canal. The annulus of Zinn divides the superior orbital fissure into three compartments through which the other orbital nerves enter the orbit. The significant blood supply to the orbit is through the ophthalmic artery, a branch of the supraclinoid portion of the ICA. This vessel follows the optic nerve in the optic canal and orbit. The ophthalmic artery crosses lateral to the optic nerve at the optic canal, and once inside the orbit, it passes above the optic nerve. At this crossing point, it usually gives rise to the central retinal artery. It is vital to avoid blind coagulation in the orbital apex as inadvertent coagulation of the retinal artery results in vision loss $[7,10]$. The superior ophthalmic vein originates in the superonasal quadrant and passes through the superior orbital fissure to drain the cavernous sinus. The supratrochlear, supraorbital, angular, maxillary, and retromandibular veins also drain the orbit.

\section{Incidence of orbital tumours}

Different studies quote varying prevalence of orbital lesions types $[1,3,11,12]$. Primary orbital tumors are sporadic with an overall incidence of less than 1 per 100,000/year. Cavernous hemangiomas, lymphoid tumours, and meningiomas account 


\begin{tabular}{|c|c|c|c|}
\hline \multicolumn{2}{|c|}{ Based on their location /compartment } & \multicolumn{2}{|c|}{ Based on the tissue of origin } \\
\hline \multicolumn{2}{|c|}{$\begin{array}{l}\text { Extraconal } \\
\text { Outside the extra-ocular muscle cone } \\
\text { These tumours can be sub periosteal or extra periosteal }\end{array}$} & \multirow{2}{*}{\multicolumn{2}{|c|}{$\begin{array}{l}\text { Primary tumours } \\
\text { Primary orbital tumours are those which originate from structures } \\
\text { within the orbit }\end{array}$}} \\
\hline \multicolumn{2}{|c|}{$\begin{array}{l}\text { Intraconal } \\
\text { The intraconal space also can be further subdivided in relation to the } \\
\text { optic nerve into medial, central, and lateral orbital spaces }\end{array}$} & & \\
\hline \multicolumn{2}{|c|}{$\begin{array}{l}\text { Intracanalicular } \\
\text { Within the optic canal }\end{array}$} & \\
\hline \multicolumn{2}{|c|}{ Anterior or preseptal compartment } & \multirow{2}{*}{\multicolumn{2}{|c|}{$\begin{array}{l}\text { Secondary tumours refer to tumours involving the orbital cavity by local } \\
\text { extension or distant metastases from other parts of the body }\end{array}$}} \\
\hline \multicolumn{2}{|c|}{$\begin{array}{l}\text { Multicompartmental } \\
\text { Lesions straddling multiple compartments }\end{array}$} & & \\
\hline \multicolumn{4}{|c|}{ Orbital tumours - classification } \\
\hline Extraconal & Intraconal & Septal/Eyelid & Multicompartmental \\
\hline $\begin{array}{l}\text { Lacrimal gland tumours } \\
\text { Dermoid cyst } \\
\text { Orbital wall meningiomas } \\
\text { Rhabdomyosarcoma } \\
\text { Mucocoele } \\
\text { Fibrous dysplasia } \\
\text { Sarcoid } \\
\text { Lymphangioma }\end{array}$ & $\begin{array}{l}\text { Globe and tumours from globe } \\
\text { Optic nerve sheath meningiomas } \\
\text { Optic nerve gliomas } \\
\text { Orbital Schwannomas } \\
\text { Cavernous hemangiomas } \\
\text { Capillary haemangioma } \\
\text { Orbital varix }\end{array}$ & $\begin{array}{l}\text { Pediatric capillary hemangioma } \\
\qquad \text { SCC } \\
\text { BCC } \\
\text { Melanoma }\end{array}$ & $\begin{array}{c}\text { Lymphoma } \\
\text { Plasmacytoma } \\
\text { Metastasis } \\
\text { Pseudotumour } \\
\text { Orbital plexiform neurofibroma }\end{array}$ \\
\hline
\end{tabular}

SCC — squamos cell carcinoma; BCC — basal cell carcinoma

for the most common primary orbital tumors in adults. In contrast, dermoid cysts, optic nerve gliomas, and rhabdomyosarcoma are the more common tumors in children. Meningiomas and sinonasal carcinomas are common tumours that extend into the orbit $[1,2,13]$. In one of the largest published series of orbital tumours, Bonovolanta et al. analysed 2,173 primary orbital tumours, 220 secondary orbital tumours, and 87 metastatic tumours in his clinical series spread over 35 years [1]. The dermoid cyst was the most frequently (14\%) encountered orbital tumor in their series, followed by cavernous hemangioma (218 cases, $9 \%$ of all cases). The most common malignant orbital tumor in his study was non-Hodgkin lymphoma, which accounted for nearly $12 \%$ of all cases [1]. Orbital tumours can be classified either based on their location or their tissue of origin (Tab. 6). Table 6 summarizes the orbital tumours based on their compartments. The commonly seen orbital tumours in our series are presented in Figures 1-8.

\section{Clinical presentation}

Clinical presentation of orbital tumours varies depending on the location of the tumour [6].
Proptosis and diplopia are the most frequent initial symptoms of an orbital mass $[12,14]$. A decrease in visual acuity as a presenting symptom is less common and indicates that tumour is situated at the orbital apex or close to the optic nerve $[1,2,13]$. Intraconal tumors tend to cause early visual loss, impairment of ocular motility, and axial proptosis from early direct compression of the optic nerve and impingement on extraocular muscles. Extraconal tumors cause proptosis as an early manifestation, displacement of the globe, and diplopia due to mechanical restriction of extraocular muscles movement [15-17].

\section{Imaging of orbital tumours}

Magnetic resonance imaging (MRI), computed tomography (CT), ultrasound (US), fluoro-2-deoxy-D-glucose positron emission tomography CT (FDG-PET CT), and MRI positron emission tomography (PET) [18-20] can be helpful in the detailed evaluation of orbital lesions. The imaging modality of choice in orbital lesions is the MRI. CT scan is reserved for lesions in which a bony pathology is suspected [18, 21]. Recommended MRI includes fat suppressed multiplanar orbital 


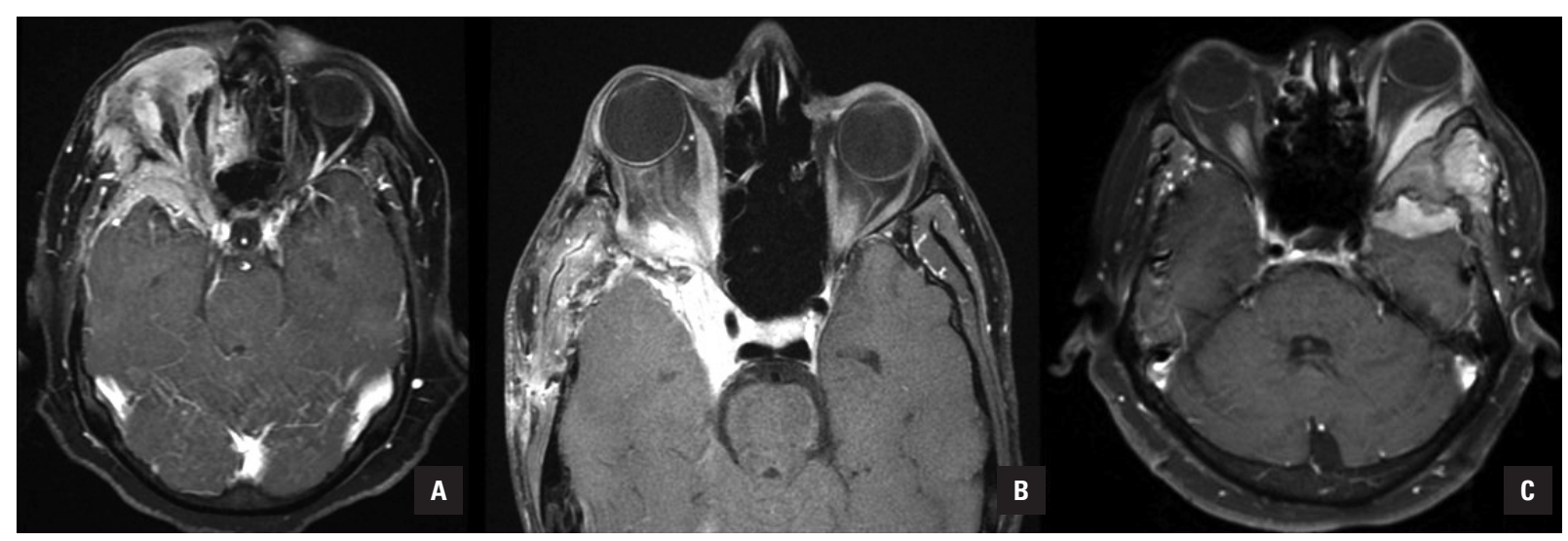

FIGURE 1. Axial MRI contrast images of three different patients $(\mathbf{A}, \mathbf{B}, \mathbf{C})$ with diffuse sphenoorbital meningiomas. Note the extension into the cavernous sinus in the second (B) and the temporal fossa in the third (C) patient

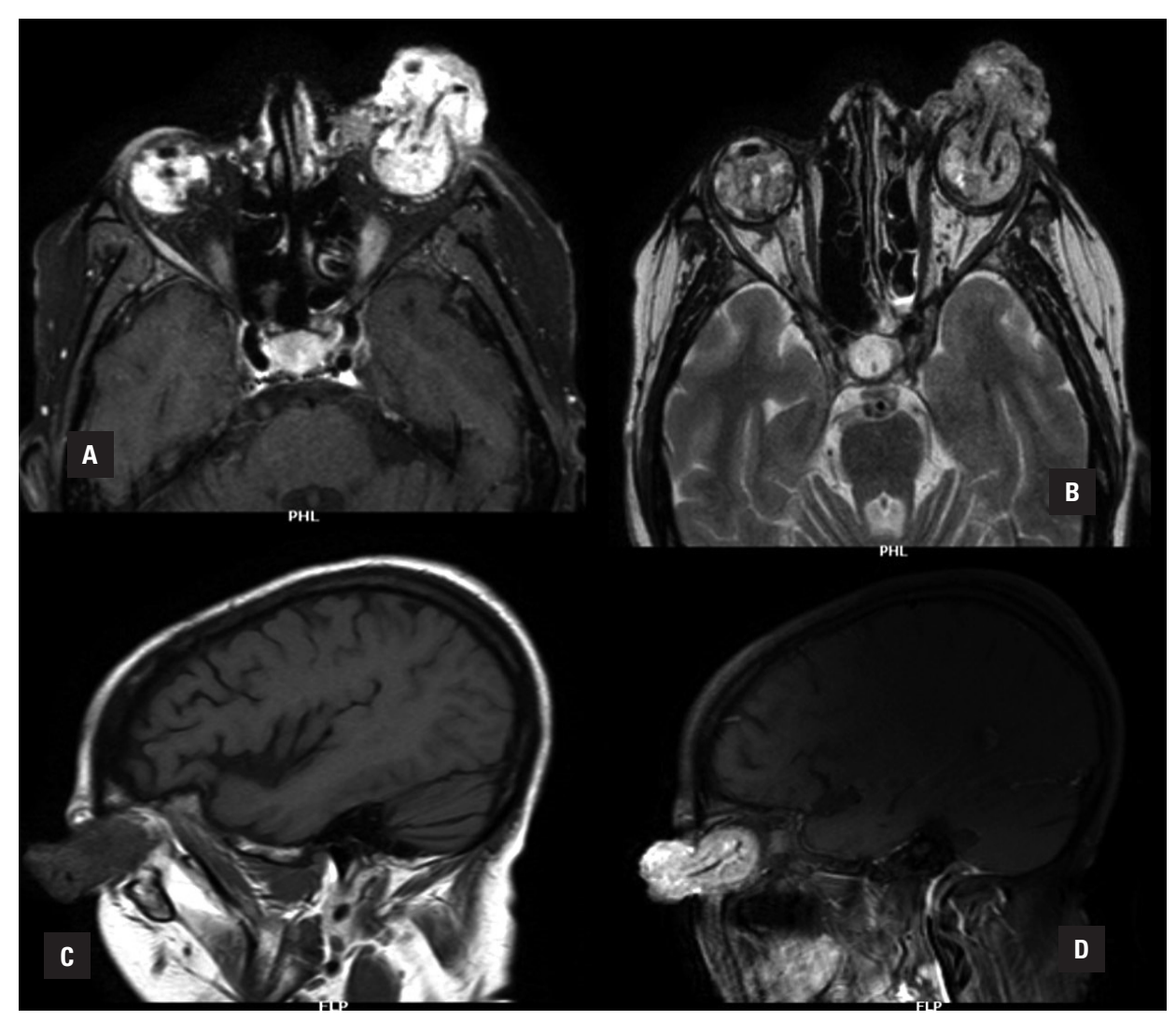

FIGURE 2. A-D. MRI axial and sagittal images of the orbit showing a retinal hemangioblastoma. The lesion shows altered signal intensity lesions isointense to hyperintense on T1 (A, C) and heterogeneously hyperintense on T2 (B) and showing significant post-contrast enhancement (D) noted in both globes

cuts with a $2-3 \mathrm{~mm}$ slice thickness with contrast administration. Ultrasound (US) with Doppler is a non-invasive and cost-effective adjunct due to the superficial location of the globe and its cystic contents. Advanced imaging techniques such as diffusion-weighted imaging (DWI), diffusion tensor imaging (DTI), FDG-PET-CT, and MRI-PET are newer modalities that supplement information acquired through MRI or CT scans. Apparent diffusion coefficient (ADC) values on echo-planar DWI help to differentiate between benign and malignant orbital masses. DTI can be used to map optic nerve fibres and assess whether the tumour displaces or infiltrates the nerve fibres. FDG-PET CT and 


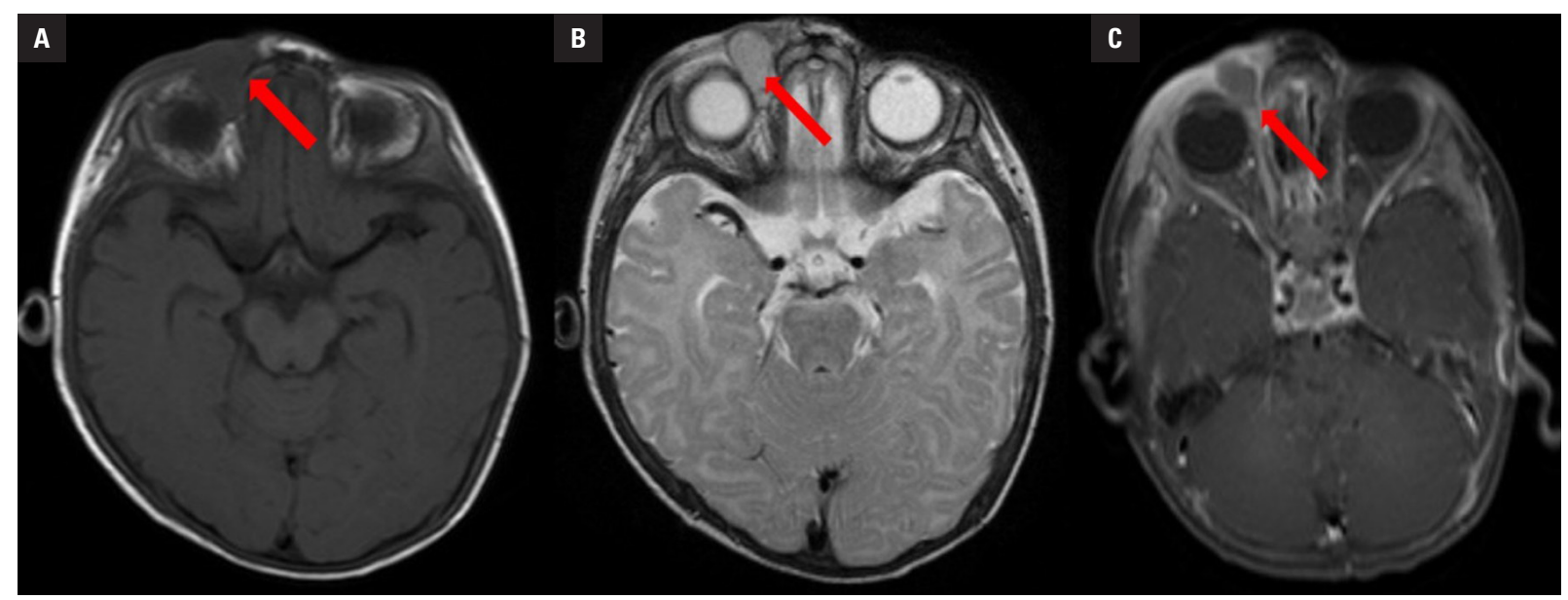

FIGURE 3. MRI plain axial T1 (A) images show a well-delineated lesion placed superomedial to the orbit, hypointense on T1, hyperintense on T2 (B), and no contrast enhancement. Biopsy of this lesion in this 3-year-old child proved it to be an embryonal rhabdomyosarcoma

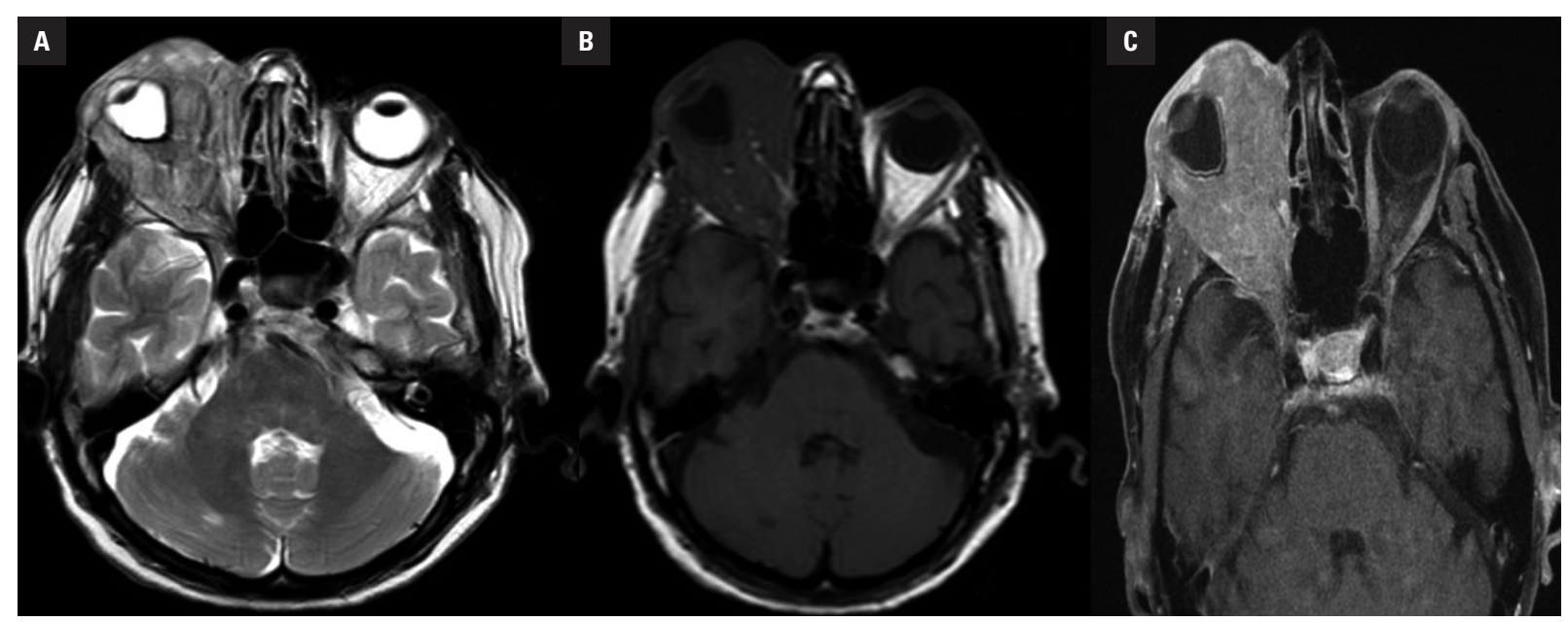

FIGURE 4. MRI orbit axial T2 (A), axial T1 (B), and contrast (C) images showing a diffuse infiltrating lymphoma involving all the compartments of the orbit

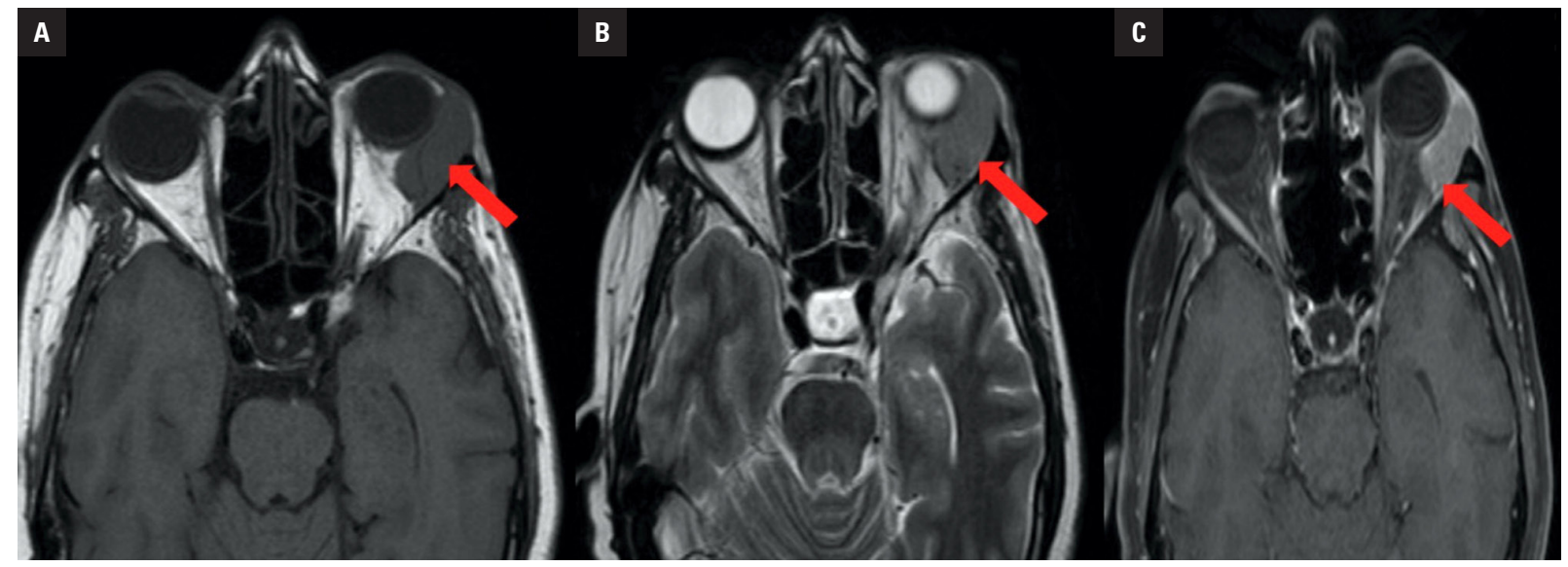

FIGURE 5. MRI orbit axial T1 (A) showing an isointense lesion in the lateral compartment in the lacrimal fossa, which remains isointense on T2 (B) and does not shows moderate contrast enhancement. Biopsy was suggestive of a lacrimal gland adenoma 


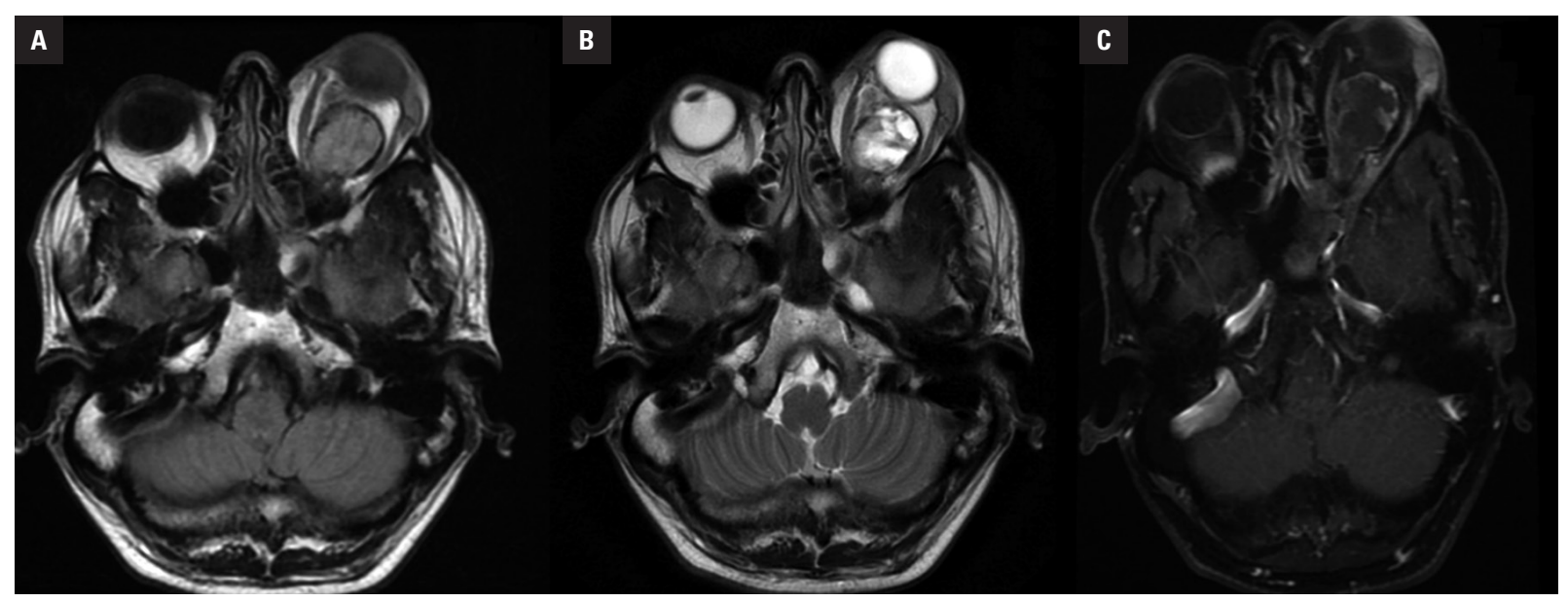

FIGURE 6. MRI orbit plain T1 (A) image showing an intraconal lesion well-demarcated, iso- to hyperintense with a hypointense rim. The optic nerve is not seen separately. Axial proptosis is evident. The lesion is hyperintense on T2 and shows patchy enhancement of the margins on contrast administration (C). Histopathology was suggestive of an optic nerve glioma

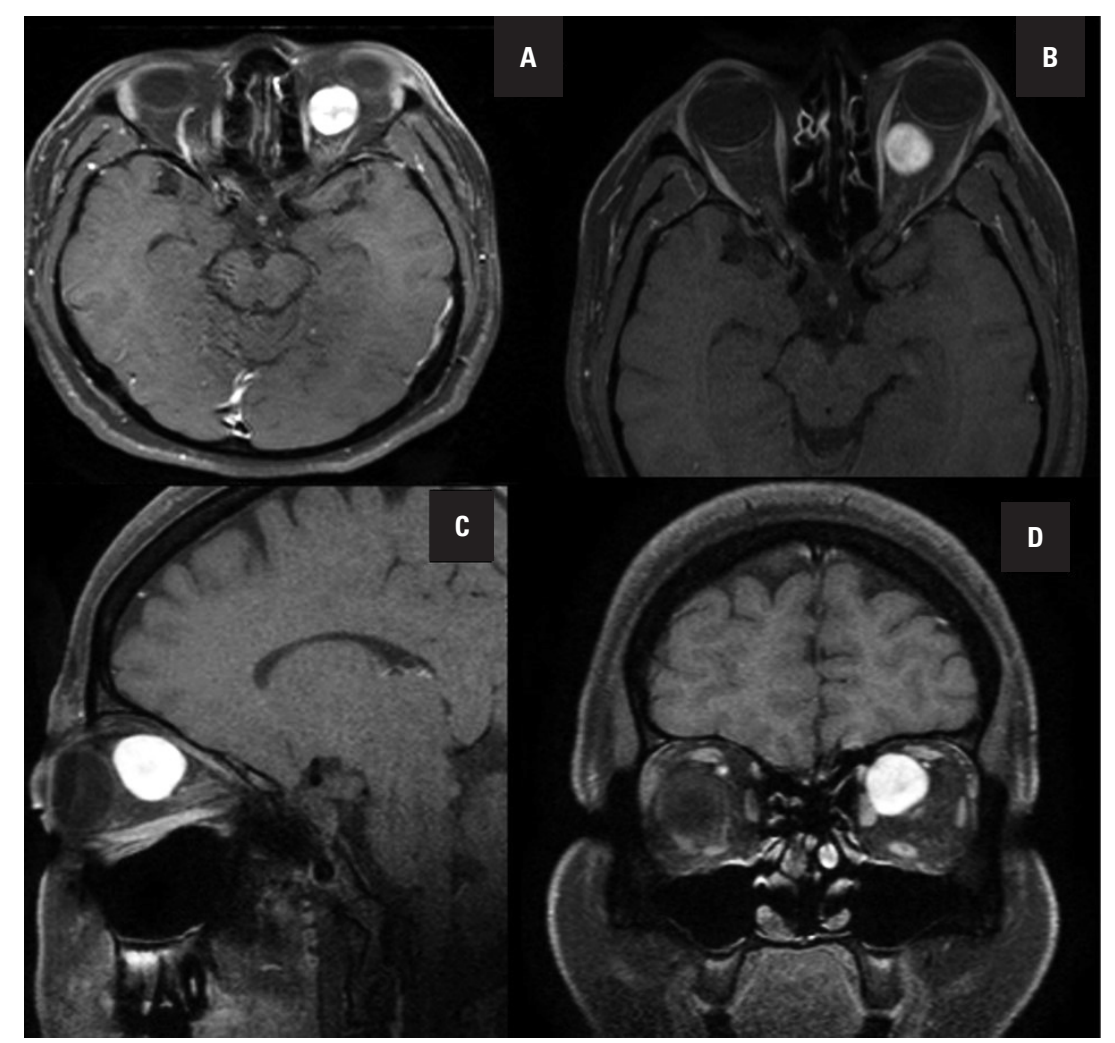

FIGURE 7. MRI axial contrast T1 (A and B) showing a well-enhancing intraconal lesion in orbit. Sagittal MRI (C) and coronal (D) images reveal the superior medial location of the schwannoma

MRI-PET provides functional information regarding tumour metabolism and is a part of standard practice in the pre-operative and post-treatment assessment of orbital malignancies. MRI-PET is superior to CT-PET in terms of reduced radiation [22].

\section{Management of orbital tumours}

Surgery remains the treatment of choice for most symptomatic orbital tumours. The aim of the surgery is gross total removal (GTR) of the tumour with preservation of function, especially 


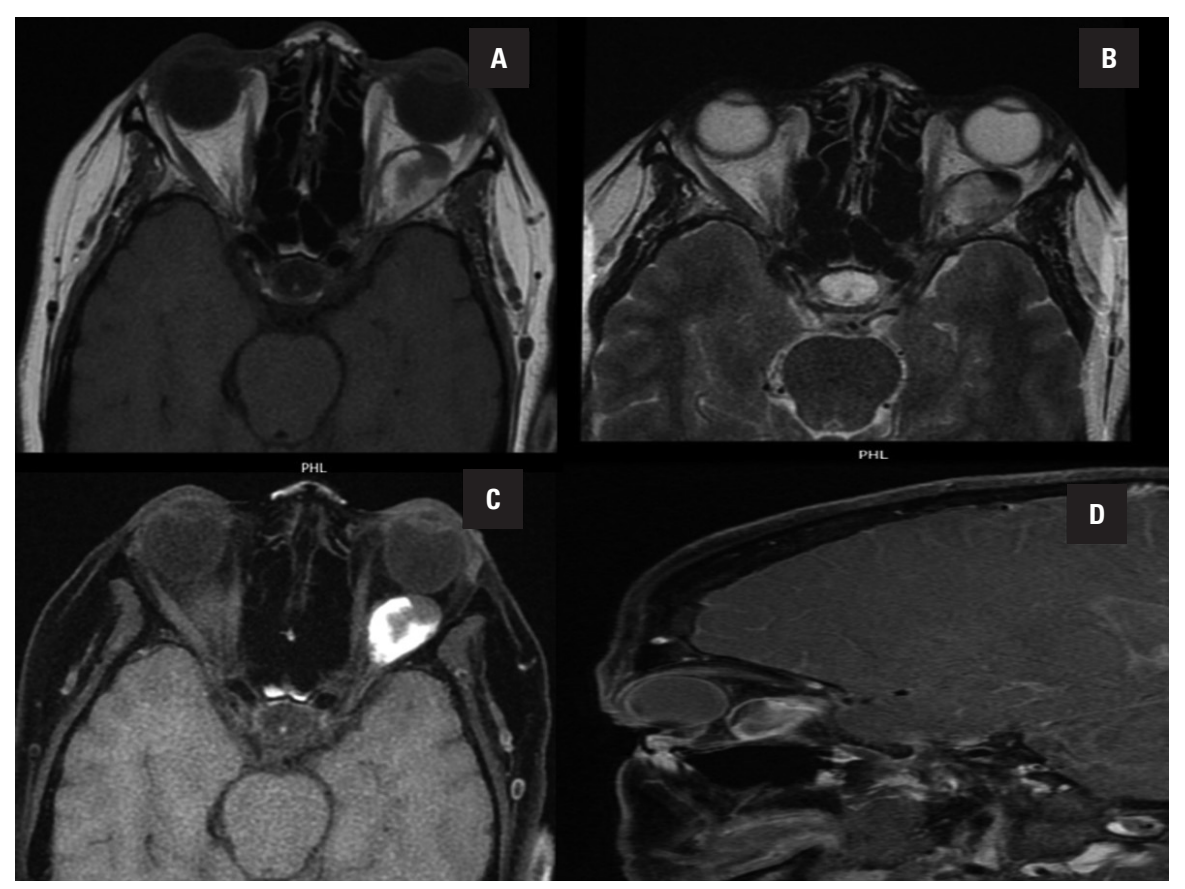

FIGURE 8. MRI orbit plain T1 shows a globular intraconal hemangioma located posterior to the globe. The lesion is of mixed-signal intensity iso-to hyperintense. The lesion on T2 remains (B) hyperintense, and contrast administration significantly enhances the hyperintense part. The sagittal images (D) reveal the location of the lesion posterior to the globe in the inferior quadrant

vision. However, for few lesions like optic nerve sheath meningioma, and optic nerve glioma, radical surgery would involve a risk of significant visual deterioration. In such instances, surgery is often delayed. Preservation of vision is preferential over exophthalmos correction. In such cases, surgery is planned if there is a risk of tumour progression intracranially or to the opposite normal nerve.

For all other tumours, the choice of a given approach depends on the location and extension of the tumour and its biological behaviour. Of these, compartmental location is the most critical criteria to finalise the approach. Paluzzi et al. were the first to suggest that the orbit should be compared to a clock and that the surgical approach to the orbit should vary based on the tumor position [23]. Approaches to the orbit can be essentially divided as transcranial, transorbital, or endonasal and combined.

\section{Transcranial approaches}

Walter Dandy, in 1922, was the first to use a transcranial fronto-temporal approach for an orbital apex tumour [24]. Subsequently, the approach went through further refinements and modifications. These include:

- Frazier's proposal of an additional removal of the supraciliary arch [25];
- the pterional approach proposed by Nafzigger [26] and modified by Yasergill [27)];

- mini-pterional approach proposed by Figueiredo et al. (28);

- Pellerin et al.'s and Hakuba et al.'s description of an orbitozygomatic approach [29];

- supraorbital approach suggested by Ormond et al. [30] .

The frontotemporal/pterional approach combined with orbital roof removal and liberal drilling of the sphenoid bone provides an excellent view of the superior and lateral aspects of the posterior orbit, better access to the optic canal, the superior orbital fissure and the anterior temporal fossa, and better accessibility of the orbital apex $[8,31]$. The orbitozygomatic variant provides an added multidirectional exposure of the anterior and middle cranial fossae, the upper clivus, and the region of the basilar apex. Tumours confined to the superior compartment of the orbit are better accessed by the supraorbital mini-craniotomy approach [32-35].

The majority of the lesions in our series were sphenoorbital meningiomas, and they were approached through an extended FTZO approach. For most of the other lesions, we preferred a frontotemporal craniotomy combined with orbitotomy as it provides optimal exposure of almost three-quarters of the globe. A suprabrow mini-craniotomy 
was reserved only for small lesions restricted to the superior compartment. Our policy was to err on the side of a larger flap which would provide greater exposure. We have observed that almost always, after incising the periorbita, the fat starts prolapsing out. In spite of adequate retraction, it becomes difficult to approach deeply located tumours. Small exposures compound the challenge. Locating the tumour is often challenging, and we have had to use the intraoperative ultrasound to localize the lesion after opening even for large tumours.

\section{Transorbital approaches}

The indications for a lateral orbital approach include: laterally placed extraconal tumors, intraconal tumours lateral or inferior to the optic nerve, lesions in the orbital apex, middle fossa, and cavernous sinus $[23,36]$. In 1889 Krönlein first described the lateral orbitotomy, and several modifications have been proposed since then [37]. When combined with a small pterional craniotomy, it provides better access to lesions situated superior and lateral to the optic nerve in orbit $[24,37]$. The total lateral orbitotomy involves additional removal of the superior orbital rim up to the superior orbital notch and the body of the zygoma. Tumors affecting the orbital apex, superior and inferior orbital fissures, and pterygopalatine are better accessed through this approach [37-40]. Our surgical approach is limited to a Kronliens hockey stick incision and removal of the zygomatic arch and lateral wall of the orbit. This, combined with liberal drilling of the lateral wall posteriorly up to the apex, provides excellent exposure to the entire lateral compartment.

\section{Anterior medial micro-orbitotomy and transconjunctival approach}

First described by Galbraith and Sullivan, anterior medial orbitotomy is helpful for anterior and medial tumours in the intraconal region of the anterior two-thirds of the orbital cavity [41]. The transconjunctival approach is preferred for surgical treatment of tumors located in the inferomedial, basal, and lateral regions of the anterior orbit. This approach is less traumatic and cosmetically more superior as it obviates the need for resection of the bone. However, the transconjunctival approach is not preferred for mediumand large-sized tumors as the surgical corridor is limited. The endoscopic endonasal approach is fast replacing this approach to access medially and inferiorly located orbital disease.
We feel that this approach is best suited for lesions in the anterior quarter of the globe, and adopting this approach for posteriorly located lesions is cumbersome. Our experience with this approach is limited to two cases, both intraocular tumours with exophytic components.

\section{Extended endonasal approaches (EEAs)}

The three main endonasal approaches to the orbit are:

1. The medial-inferior extraconal approach.

2. The trans maxillary extraconal approach.

3. The medial intraconal approach.

Together, these approaches provide excellent exposure for the safe removal of most intraconal and extraconal tumors that lie medial and inferior to the optic nerve. Endoscopic approaches have almost become the standard of care for medially posteriorly located orbital lesions. Total endoscopic removal of such orbital lesions has a significant learning curve even for established endoscopic surgeons [42-44].

\section{Extent of resection}

Our patient cohort was disproportionate with a relatively large number of sphenoorbital meningiomas where GTR is extremely difficult due to the invasive nature of the disease. We achieved a nearly 80\% GTR with FTO, 83\% with Lateral orbitotomy, and $75 \%$ with SMC for the other lesions. It was the primary nature of the lesion which influenced the GTR rather than the approach. Lesions, where GTR was not possible, were diffuse with poor margins. We have observed that the majority of the orbital tumours can be successfully removed through either an FTC or lateral orbitotomy. The best technique to remove the tumours in the medial compartment is an endoscopic approach, especially if they are inferiorly and posteriorly situated. Another interesting observation in our series was that intraconal lesions had a better rate of GTR compared to extraconal lesions. Intraconal lesions are more likely to be well-circumscribed (e.g., neurofibroma) than extraconal lesions, which could explain this observation. Primary tumours similarly had a better rate of GTR, again related to the intrinsic pathology of the lesion.

\section{CONCLUSION}

Orbital tumours comprise a rare and challenging spectrum of pathologies that are best tackled by an 
interdisciplinary approach. Thorough knowledge of anatomy and the combined experience of a neurosurgeon, ophthalmologist, and endoscopic surgeon is a prerequisite for the successful management of orbital tumours. The majority of the orbital lesions can be effectively operated through one of the three following approaches - fronto-temporo-orbital approach, a lateral orbitotomy, or an endoscopic approach. Intraconal primary benign orbital tumours have a better chance of GTR. The nature and pathology of the lesion influence the extent of resection rather than the location of the lesion.

\section{Acknowledgments}

None declared.

\section{Financial disclosures}

None declared.

\section{Funding}

None declared.

\section{Conflicts of interest}

None declared.

\section{REFERENCES}

1. Bonavolontà $G$, Strianese $D$, Grassi $P$, et al. An analysis of 2,480 spaceoccupying lesions of the orbit from 1976 to 2011. Ophthalmic Plast Reconstr Surg. 2013; 29(2): 79-86, doi: 10.1097/IOP.0b013e31827a7622, indexed in Pubmed: 23470516.

2. Hasegawa M. Differential Diagnosis and Pathogenesis for Orbital Tumors. Japan J Neurosurg. 2017; 26(6): 419-429, doi: 10.7887/ jens.26.419.

3. Shinder R, Al-Zubidi N, Esmaeli B. Survey of orbital tumors at a comprehensive cancer center in the United States. Head Neck. 2011; 33(5): 610-614, doi: 10.1002/hed.21498, indexed in Pubmed: 20824811.

4. Park HJ, Yang SH, Kim IIS, et al. Surgical treatment of orbital tumors at a single institution. J Korean Neurosurg Soc. 2008; 44(3): 146-150, doi: 10.3340/jkns.2008.44.3.146, indexed in Pubmed: 19096665.

5. Scarone $P$, Leclerq $D$, Héran $F$, et al. Long-term results with exophthalmos in a surgical series of 30 sphenoorbital meningiomas. Clinical article. J Neurosurg. 2009; 111(5): 1069-1077, doi: 10.3171/2009.1.JNS081263, indexed in Pubmed: 19267523.

6. Kannan S, Hasegawa M, Yamada Y, et al. Tumors of the Orbit: Case Report and Review of Surgical Corridors and Current Options. Asian J Neurosurg. 2019; 14(3): 678-685, doi: 10.4103/ajns.AJNS 51 19, indexed in Pubmed: 31497084.

7. Martins C, Costa E Silva IE, Campero A, et al. Microsurgical anatomy of the orbit: the rule of seven. Anat Res Int. 2011; 2011: 468727, doi: 10.1155/2011/468727, indexed in Pubmed: 22567293.

8. Maroon JC, Kennerdell JS. Surgical approaches to the orbit. Indications and techniques. J Neurosurg. 1984; 60(6): 1226-1235, doi: 10.3171/ jns.1984.60.6.1226, indexed in Pubmed: 6726367.

9. Kennerdell JS, Maroon JC, Malton ML. Surgical approaches to orbital tumors. Clin Plast Surg. 1988; 15(2): 273-282, indexed in Pubmed: 3349739.

10. Campbell AA, Grob SR, Yoon MK. Novel Surgical Approaches to the Orbit. Middle East Afr J Ophthalmol. 2015; 22(4): 435-441, doi: 10.4103/0974-9233.164613, indexed in Pubmed: 26692713.

11. Ohtsuka K, Hashimoto M, Suzuki Y. A review of 244 orbital tumors in Japanese patients during a 21-year period: origins and locations. Jpn
J Ophthalmol. 2005; 49(1): 49-55, doi: 10.1007/s10384-004-0147-y, indexed in Pubmed: 15692775.

12. Shields JA, Shields CL, Scartozzi R. Survey of 1264 patients with orbital tumors and simulating lesions: The 2002 Montgomery Lecture, part 1. Ophthalmology. 2004; 111(5): 997-1008, doi: 10.1016/j. ophtha.2003.01.002, indexed in Pubmed: 15121380.

13. Pförtner R, Mohr C, Daamen J, et al. Orbital tumors: operative and therapeutic strategies. Facial Plast Surg. 2014; 30(5): 570-577, doi: 10.1055/s-0034-1395210, indexed in Pubmed: 25397713.

14. Montano N, Lauretti L, D'Alessandris QG, et al. Orbital Tumors: Report of 70 Surgically Treated Cases. World Neurosurg. 2018; 119: e449-e458, doi: 10.1016/j.wneu.2018.07.181, indexed in Pubmed: 30071324.

15. Rootman J. Diseases of the orbit. 2nd ed. Lippincott Williams \& Wilkins, Philadelphia 2003: 579.

16. Alkatan HM, Al Marek F, Elkhamary S. Demographics of Pediatric Orbital Lesions: A Tertiary Eye Center Experience in Saudi Arabia. J Epidemiol Glob Health. 2019; 9(1): 3-10, doi: 10.2991/jegh.k.181224.001, indexed in Pubmed: 30932383.

17. Garrity JA, Henderson JW, Cameron JD. Henderson's orbital tumors. 4th ed . Lippincott Williams \& Wilkins, Philadelphia : 404.

18. Purohit BS, Vargas MI, Ailianou A, et al. Orbital tumours and tumourlike lesions: exploring the armamentarium of multiparametric imaging. Insights Imaging. 2016; 7(1): 43-68, doi: 10.1007/s13244-015-0443-8, indexed in Pubmed: 26518678.

19. Goh PS, Gi MT, Charlton A, et al. Review of orbital imaging. Eur J Radiol. 2008; 66(3): 387-395, doi: 10.1016/j.ejrad.2008.03.031, indexed in Pubmed: 18501542.

20. Razek AA, Elkhamary S, Mousa A. Differentiation between benign and malignant orbital tumors at 3-T diffusion MR-imaging. Neuroradiology. 2011; 53(7): 517-522, doi: 10.1007/s00234-011-0838-2, indexed in Pubmed: 21286695.

21. Hasegawa M, Fujisawa $H$, Hayashi $Y$, et al. CT arteriography for orbital tumors: diagnostic and surgical value. J Clin Neurosci. 2005; 12(5): 548-552, doi: 10.1016/j.jocn.2004.08.012, indexed in Pubmed: 15982890.

22. Miyamoto J, Tatsuzawa K, Owada K, et al. Usefulness and limitations of fluorine-18-fluorodeoxyglucose positron emission tomography for the detection of malignancy of orbital tumors. Neurol Med Chir (Tokyo). 2008; 48(11): 495-9; discussion 499, doi: 10.2176/nmc.48.495, indexed in Pubmed: 19029776.

23. Paluzzi A, Gardner PA, Fernandez-Miranda JC, et al. „Round-the-Clock” Surgical Access to the Orbit. J Neurol Surg B Skull Base. 2015; 76(1): 12-24, doi: 10.1055/s-0033-1360580, indexed in Pubmed: 25685644.

24. Dandy W. Prechiasmal Intracranial Tumors of the Optic Nerves. Am J Ophthalmol. 1922; 5(3): 169-188, doi: 10.1016/s0002 9394(22)90261-2.

25. Khan AM, Varvares MA. Traditional approaches to the orbit. Otolaryngol Clin North Am. 2006; 39(5): 895-909, vi, doi: 10.1016/j. otc.2006.08.008, indexed in Pubmed: 16982253.

26. Naffziger H. Pathologic changes in the orbit in progressive exophthalmos. Arch Ophthalmol. 1933; 9(1): 1, doi: 10.1001/archopht.1933.00830010004001.

27. Yaşargil MG, Reichman MV, Kubik S. Preservation of the frontotemporal branch of the facial nerve using the interfascial temporalis flap for pterional craniotomy. Technical article. J Neurosurg. 1987; 67(3): 463-466, doi: 10.3171/jns.1987.67.3.0463, indexed in Pubmed: 3612281.

28. Figueiredo EG, Zabramski JM, Deshmukh P, et al. Anatomical and quantitative description of the transcavernous approach to interpeduncular and prepontine cisterns. Technical note. J Neurosurg. 2006; 104(6): 957-964, doi: 10.3171/jns.2006.104.6.957, indexed in Pubmed: 16776341.

29. Pellerin $P$, Lesoin $F$, Dhellemmes $P$, et al. Usefulness of the orbitofrontomalar approach associated with bone reconstruction for frontotemporosphenoid meningiomas. Neurosurgery. 1984; 15(5): 715-718, doi: 10.1227/00006123-198411000-00016, indexed in Pubmed: 6504290.

30. Ormond DR, Hadjipanayis CG. The Supraorbital Keyhole Craniotomy through an Eyebrow Incision: Its Origins and Evolution. Minim Invasive 
Surg. 2013; 2013: 296469, doi: 10.1155/2013/296469, indexed in Pubmed: 23936644

31. Humphrey C, Kriet J. Surgical approaches to the orbit. Operat Tech Otolaryngol-Head Neck Surg. 2008; 19(2): 132-139, doi: 10.1016/j. otot.2008.07.002

32. da Silva SA, Yamaki VN, Solla DJ, et al. Pterional, Pretemporal, and Orbitozygomatic Approaches: Anatomic and Comparative Study. World Neurosurg. 2019; 121: e398-e403, doi: 10.1016/..wneu.2018.09.120, indexed in Pubmed: 30266695.

33. Reisch R, Perneczky A, Filippi R. Surgical technique of the supraorbital key-hole craniotomy. Surg Neurol. 2003; 59(3): 223-227, doi: 10.1016/ s0090-3019(02)01037-6, indexed in Pubmed: 12681560.

34. Srinivasan A, Bilyk JR. Transcranial Approaches to the Orbit. Int Ophthalmol Clin. 2018; 58(2): 101-110, doi: 10.1097/ II0.0000000000000224, indexed in Pubmed: 29517647.

35. Hamby WB. Pterional approach to the orbits for decompression or tumor removal. J Neurosurg. 1964; 21: 15-18, doi: 10.3171/ ins.1964.21.1.0015, indexed in Pubmed: 14110353.

36. Abou-Al-Shaar H, Krisht KM, Cohen MA, et al. Cranio-Orbital and Orbitocranial Approaches to Orbital and Intracranial Disease: Eye-Opening Approaches for Neurosurgeons. Front Surg. 2020; 7: 1, doi: 10.3389/ fsurg.2020.00001, indexed in Pubmed: 32118028.

37. Stallard HB. Lateral orbitotomy (Krönlein's Operation). Br J Ophthalmol. 1946; 30(4): 250-251, indexed in Pubmed: 18170216.
38. Kim JW, Yates BS, Goldberg RA. Total lateral orbitotomy. Orbit. 2009; 28(6): 320-327, doi: 10.3109/01676830903334028, indexed in Pubmed: 19929652.

39. Nemet A, Martin P. The lateral triangle flap--a new approach forlateral orbitotomy. Orbit. 2007; 26(2): 89-95, doi: 10.1080/01676830600974571, indexed in Pubmed: 17613854.

40. Chabot JD, Gardner PA, Stefko ST, et al. Lateral Orbitotomy Approach for Lesions Involving the Middle Fossa: A Retrospective Review of Thirteen Patients. Neurosurgery. 2017; 80(2): 309-322, doi: 10.1093/ neuros/nyw045, indexed in Pubmed: 28175869.

41. Sullivan GL. Caveat chirurgicus. Trans Am Ophthalmol Soc. 1972; 70 : 328-336, indexed in Pubmed: 4663672.

42. Signorelli $F$, Anile C, Rigante M, et al. Endoscopic treatment of orbital tumors. World J Clin Cases. 2015; 3(3): 270-274, doi: 10.12998/wjcc. v3.i3.270, indexed in Pubmed: 25789299.

43. Campbell PG, Yadla S, Rosen M, et al. Endoscopic transnasal cryoassisted removal of an orbital cavernous hemangioma: a technical note. Minim Invasive Neurosurg. 2011; 54(1): 41-43, doi: 10.1055/s0030-1270465, indexed in Pubmed: 21509724.

44. Koutourousiou M, Gardner PA, Stefko ST, et al. Combined endoscopic endonasal transorbital approach with transconjunctival-medial orbitotomy for excisional biopsy of the optic nerve: technical note. J Neurol Surg Rep. 2012; 73(1): 52-56, doi: 10.1055/s-0032-1323156, indexed in Pubmed: 23946927. 